AWEJ for Translation \& Literary Studies Volume, 1 Number 3, August 2017

Pp.162-176

DOI: http://dx.doi.org/10.24093/awejtls/vol1no3.11

\title{
The Usefulness of Translation in Foreign Language Teaching: Teachers' Attitudes and Perceptions
}

\author{
Dalila Benelhadj Djelloul \\ Department of English, Faculty of Letters and Arts \\ University of Mostaganem, Algeria \\ Bel Abbes Neddar \\ Department of English, Faculty of Letters and Arts \\ University of Mostaganem, Algeria
}

\begin{abstract}
Translation has long been viewed as an ineffective pedagogical tool due to its unjustifiable association to old methods of teaching, particularly the Grammar-Translation Method (GTM) and its practices. The overuse and the misuse of translation in the heydays of these methods paved the way to the monolingual assumption that English should be taught without the inclusion of translation activities in the classroom. However, in the last few decades, there has been ongoing research re-evaluating the use of translation in the EFL context. Drawing upon several studies conducted in this respect, researchers discussed the main objections raised against the use of translation and set the benefits of this teaching tool in facilitating the students' language learning process. On the basis of the findings of these studies, the present article aims at exploring teachers' attitudes towards the use and usefulness of translation in English classes in the Algerian EFL context. Due to the huge gap between the literature on the importance of translation and its practice on the ground, this article attempts to confirm the validity of this pedagogical tool and suggest some guidelines as to how and when to integrate translation activities within the teaching of English as a foreign language. The data were collected through a questionnaire addressed to secondary school teachers working in different cities in Algeria. Though it has never been practised in a principled and purposeful way, translation, has gained a wide recognition from secondary school teachers who reported that this pedagogical tool played a considerable role in facilitating foreign language learning and improving language skills. The findings confirmed the effectiveness of translation in explaining new vocabulary, developing students' cognitive skills and extending students' background knowledge as well as their linguistic competence.
\end{abstract}

Key words: EFL, Grammar-Translation Method (GTM), pedagogical translation, teachers' attitudes and perceptions, translation

Cite as: Benelhadj Djelloul, D., \& Neddar, B. A. (2017). The Usefulness of Translation in Foreign Language Teaching: Teachers' Attitudes and Perceptions. Arab World English Journal for Translation \& Literary Studies, 1(3). DOI: http://dx.doi.org/10.24093/awejtls/vol1no3.11 